\title{
接触メディアが大阪都構想を巡る有権者の 政策判断に及ぼす影響に関する実証的研究
}

\author{
宮川 愛由 1 ・田中 謙士朗 2 ・藤井 聡 3 \\ 1 正会員 京都大学大学院助教 工学研究科都市社会工学専攻 \\ （干615-8540 京都府京都市西京区京都大学桂 4) \\ E-mail: miyakawa@trans.kuciv.kyoto-u.ac.jp \\ 2 学生会員 京都大学大学院工学研究科都市社会工学専攻（同上） \\ E-mail:k.tanaka@trans.kuciv.kyoto-u.ac.jp \\ 3 正会員 京都大学大学院教授 工学研究科都市社会工学専攻（同上） \\ E-mail: fujii@trans.kuciv.kyoto-u.ac.jp
}

\begin{abstract}
本研究は都市計画，土木計画に抜本的な影響を及ぼす地方政府の統治機構改革を決する政治プロセスの 合理化に資する効果的なコミュニケーションについての実証的知見を得る事を目的として，大阪市を廃止 して都区制度を導入する, 所謂「大阪都構想」を巡る住民投票を事例として, 有権者の接触メディアと政 策判断との関係性を分析した。その結果，テレビや新聞といった両論併記が原則となる情報媒体を参考に する傾向が高い有権者は，情報の真偽の判断が困難となるが故に従前の意見を変化させない一方で，意見 を変化させた人々の内，「反対」に転じた人々は精緻化見込理論でいうところの事実情報に基づく「中心 ルート」によって，「賛成」に転じた人々は「周辺ルート」によって態度を変容させたことを示唆する分 析結果が示された.
\end{abstract}

Key Words : media, communication, innovation authority, policy decision

\section{1. 背景と目的}

(1) 都市計画・土木計画を決定づける統治機構改革

一般に都市計画，土木計画は私的機関が執り行うも のではなく，「政府」が行うものである．中でも，都市 計画や地域的な土木計画の推進においては地方政府が重 大な役割を担う。そして，地方政府の都市計画，土木計 画の推進にあたっては，その「統治機構」として如何な る形式が採択されているのかが重大な影響を持つ. 個々 の都市計画，土木計画の諸事業の財源と政治的意思決定 プロセスは，その地方政府の統治機構の形式に直接的に 依存しているからである.

一方で，個々の地方政府の「統治機構」は，戦後， 新憲法制定と共に個々の地方に於いて措定されて以来, 基本的に大きな変革をされないまま今日に至っている. しかし，今日では道州制の導入をはじめとして，そのあ り方を大きく改変，変革する議論が，一定の現実性を伴 う形で展開されている，そうした統治機構改革の流れの 中で，最も抜本的な改革が実現される可能性が高いもの として，大阪市を廃止して都区制度を導入する，いわゆ
る「大阪都構想」あるいは「大阪市廃止分割構想」があ る. すなわち，この構想が実現すれば，大阪と言う一つ の地域の統治機構が抜本的に改革され, それに伴って, この地域の都市計画，土木計画の内実が抜本的に変革さ れることが予期されるのである ${ }^{1)}$ ，そして言うまでもな く, 統治機構の改革の実施の有無において合理的な政治 的判断が下されなければ, 都市計画, 土木計画の合理化 もまた大きく阻害されることとなる。したがって，合理 的な都市計画，土木計画を志す上では，統治機構改革に ついての政治プロセスにおいて合理的な議論が展開され ることを期することが必要不可欠だという事になる。こ こでいう「合理的」とは，イメージや感情に依らず，事 実情報に基づく理性的な判断がなされる状況を意味する. そしてそのためには，どのようなコミュニケーションを 公共的に展開していくことが求められるのかを明らかに することが必要になる。ついては本研究では, 都市計画, 土木計画に抜本的な影響を及ぼす地方政府の統治機構改 革を決する政治プロセスの合理化を図る上で，如何なる コミュニケーションを展開することが効果的であるのか についての実証的知見を得る事を目的とする. 


\section{（2） 大阪都構想 $=$ 大阪市廃止分割構想の住民投票}

ところで，そもそも政治とは統治者・為政者が民に 施す施策であり 2)，政治によって施行される政策は国家， 国民に対して長期的，広域的に多大な影響を及ぼす重要 なものである.したがって，政策の立案・策定段階にお いては，政策内容の十分な検討が求められることは論を 俟たない，そしてその政治形態として，我が国をはじめ 多くの先進諸国では，国民が自己の意思の反映である代 表者を選出し，その代表者に政治の運営を任せる間接民 主制が採用されている，そうした代議機関は，どんな個 人より熟慮することにおいて優れており，代議機関に求 められるのは話し合いであるとの指摘があるように ${ }^{3)}$,

こうした政治形態が採用されてきた背景として，適切な 議論が求められていると言えよう.

一方で，1990年代以降に始まった地方分権改革は，住 民自らが地域を統治していく住民自治の動きを活発化さ せた．その象徵ともいえる住民投票の実施件数は 2010 年 (平成 22 年) 時点で実に 500 件近くに上るとされる ${ }^{4}$ ) 住民投票は，[1]地方自治特別法の制定の可否を問うも の, [2]地方議会の解散要求や議員・首長の解職要求な どの直接請求を受けて賛否を問うもの，[3]条例に基づ くものの 3 種類に大別できる. これまでわが国で実施さ れてきた住民投票の 8 割以上が[3]条例に基づく住民投票 であり，この投票結果に法的拘束力はない。一方，2015 年 5 月 17 日，「大都市地域における特別区の設置に関 する法律」に基づき実施された大阪市特別区設置住民投 票は, [1]地方自治特別法の制定の可否を問うものに該 当し，この投票結果は法的拘束力を伴う. 政令指定都市 制度そのもの是非を住民に直接問う全国初の住民投票と して，全国的も大きな注目を集めた．投票日当日まで賛 成・反対両派による論戦が繰り広げられ，また市民の政 策への理解を深めるための大阪市主催の説明会もたびた び開かれた. 今回の住民投票の当日有権者数は 210 万 4,076 人で，投票率は $66.83 \%$ であった. 大阪市内全域で 行われた国政，地方選挙と比べると，過去最高だった 1951年の大阪市長・市議選の $71.98 \%$ には及ばなかったも のの, 最近 10 年で最も高かった 2009 年の衆院選の $65.0 \%$ や，大阪府知事選とのダブルで行われた 11 年の市長選 の 60.92\%を上回った 5). 投票の結果, 否決となったが, 賛成 694,844 票 (49.6\%)，反対 705,585 票（50.4\%）とそ の差は僅差であった.

\section{（3）有権者の政治判断と接触メディアの関係}

住民投票は住民の意思を直接的に集計する手法であり， 社会的な意思決定の一つである。一方で，その意志決定 には多くの限界が指摘されている。 これについて, 羽鳥 等は，第 1 に，投票に参加する個人が必ずしも合理的主 体ではなく, 心理的・感情的な動機に左右されること，
第 2 に，合理的な個人であっても，投票を棄権すること があり, 多くの有権者が棄権した場合, 投票結果が覆る 可能性がある，第3に，有権者が充分な情報を有さず， 誤った信念に基づき投票する場合がある，という 3 点を 挙げている の. 本研究は上記の第 1 と第 3 の課題に着目 する．これまで，間接民主制に基づく選挙における有権 者の投票行動と接触メディアの関係性に関する研究は数 多く蓄積されており，上記の指摘を裏付ける経験的事実 が確認されている例於 7,8)，一方で，筆者らが知る限り， 住民投票という直接民主制の政治プロセスを対象として， 有権者の意思決定と接触メディアの関係性に焦点を当て た研究は見当たらない，そこで本研究では，上記の(1) で述べた研究目的を達成する手段として，大阪都構想の 住民投票前後に大阪市民を対象として実施したアンケー 卜調査に基づき，有権者の接触メディアと政策判断との 関係性を実証的に明らかにすることとした。

先述の通り，先の大阪都構想を巡る住民投票は，法的 拘束力を有する過去に例を見ない重大な直接民主制の政 治プロセスが採用された極めて稀有な事例であり，今後 の住民投票等の直接民主制の政治プロセスをどのように 運用すべきかを考える上で，有権者が如何なる情報を参 考にし，その情報が政策の政策判断にどのような影響を 与えたかを明らかにすることは，貴重な情報となると考 えられる，なお，本研究では，賛否意見についての世論 の「変化方向」に関する知見を得ることを目的として， 住民投票前後で「賛否に変化が見られた」対象者を選定 し，接触メディアと賛否変化との関係性を明らかにする 分析を行う．なお，その変化の「速度」についての知見 を得るためには，賛否に変化が無かった人々も含めて， 意見の変化がいつ生じるのか, 逆にいうなら意見はどの 程度持続していくのかに着目していくことが必要である が，その点については，今後の課題としたい．

\section{2. 方法}

\section{(1) 調査概要}

本研究では，大阪都構想を巡る有権者の投票判断が如 何なる情報によって影響を受けたのかを検証するために， 大手インターネット調査会社マクロミルのリサーチモニ ターに登録している大阪市民を対象として，大阪市特別 区設置住民投票の前後（住民投票前 : 2015 年 2 月 13 18 日実施，住民投票後 : 2015 年 5 月 25 日～27 日実施） 2 回 のWeb アンケート調查を実施した。 なお，調査は調査 会社からリサーチモニターに対してメール配信されるも のであるが，その際，調査実施主体は記載されない．住 民投票前の調査では，6,177 名，住民投票後の調査にお いては，1,030 名から回答を得た。なお，両調査はパネ 
ルデータとなっており，事後調査では各年代（20代，30 代，40代，50代，60歳以上），性別で，各1割となるよ よう対象サンプルを均等に割り付けた.

\section{(2) 調査項目}

以下に各調査内容を示す，なお，本調査では，以下に 述べる調査項目以外にも, 都構想に対寸るイメージや橋 下徹大阪市長に対する評価等を尋衫ているが，誌面の都 合上，全調査項目の概略の夕付表-1に示寸，なお，キャ リーオーバー効果を避けるため, 「都構想に対するイメ ージ」や「橋下徹大阪市長に対する評価」，以下に述べ る「d）都構想に対する期待」及び「e）都構想に関す る情報の評価」は，全て事前調査における「賛否意識」 の後に設問を設けている．また，事前事後共に，d)，e) の各小問間におけるキャリーオーバー効果を避けるため, 各小問が回答者にランダムに提示されるよう設定した.

\section{a) 都構想内容認知 (事前)}

都構想の内容についての認知度を測定するため,「大 阪都構想の内容を知っていますか?」という質問を設定 し，「全く知らない」から「よく知っている」の 5 件法 で回答を要請した．なお，この問において，多くの回答 者が想定した都構想の「内容」は，橋下市長はじめ都構 想推進派がキャッチフレーズとしていた，大阪府と大阪 市の二重行政のムダを無く寸，というものであった可能 性が考えられる.

\section{b) 住民投票参加意向}

住民投票への参加意思を測定するため，「大阪都構想 を巡る住民投票に行こうと思いますか.」という質問を 設定し，「必ず行く」，「多分行く」，「わからない」, 「多分行かない」，「絶対行かない」の 5 件法で回答を 要請した.

\section{C) 都構想賛否 (事前)}

都構想への賛否意識を測定するため,「大阪都構想に 賛成ですか?」という質問を設定し，「賛成」から「反 対」までの 5件法で回答を要請した.

\section{d) 都構想に対する期待 (事前・事後)}

都構想実現によって期待されることについて，「大阪 「府」はよくなると思う」，「大阪「市」はよくなると う」，「日本はよくなると思う」，「大阪の雇用が増え ると思う」，「大阪の経済は活性化すると思う」，「二 重行政による無駄がなくなると思う」，「住民の声が役 所に反映されやすくなると思う」，「大阪市民の税金負 担が軽減すると思う」，「行政が混乱すると思う」，

「住民サービスが低下すると思う」，「財政が健全化す ると思う」，「大阪も東京の様に発展すると思う」， 「改革が進むと思う」，「大阪の歴史や文化が壊される と思う」，「カジノを含む統合型リゾートの誘致が進む と思う」について，それぞれ，「とてもそう思う」から
「全くそう思わない」の7件法で回答を要請した.

\section{e）都構想に関する情報の評価 (事後)}

都構想に関する情報に対する評価として，「大阪都構 想に関するのメディアの報道は偏っていたと思う」，

「大阪都構想の反対派は，デマばかり言っていた」，

「大阪都構想の賛成派は，デマばかり言っていた」につ いて，それぞれ，「とてもそう思う」から「全くそう思 わない」の7件法で回答を要請した.

\section{f）都構想参考情報 (事前·事後)}

都構想に関してメディアの情報をどの程度参考にして いるのかについて，住民投票前の調査では，「読売新 聞」, 「朝日新聞」, 「毎日新聞」, 「日経新聞」, 「産経新聞」,「地方紙」,「スポーツ新聞」,「テレ ビ」,「インターネット」,「タウンミーティング」,

「橋下徹氏の Twitter」, 「大阪維新の会のホームペー ジ」，「周囲の人の意見」，「学者や専門家の意見」の 計 14 項目について, 住民投票後の調査では, これら 14 項目に加えて, 「橋下徹氏の街頭演説」, 「橋下徹氏の テレビ出演」，「都構想の「効果」を主張する学者や専 門家の意見」，「都構想の「危険性」を指摘する学者や 専門家の意見」，「都構想の「効果」を主張するチラ シ」，「都構想の「危険性」を指摘するチラシ書籍」の 計 20 項目について，「見聞きしていない」，「見聞き したが，全く参考にしなかった」，「見聞きしたが，余 り参考にしなかった」，「少し参考にした」，「非常に 参考にした」の5段階の選択肢を設定した.

表-1 回答者属性・基本集計

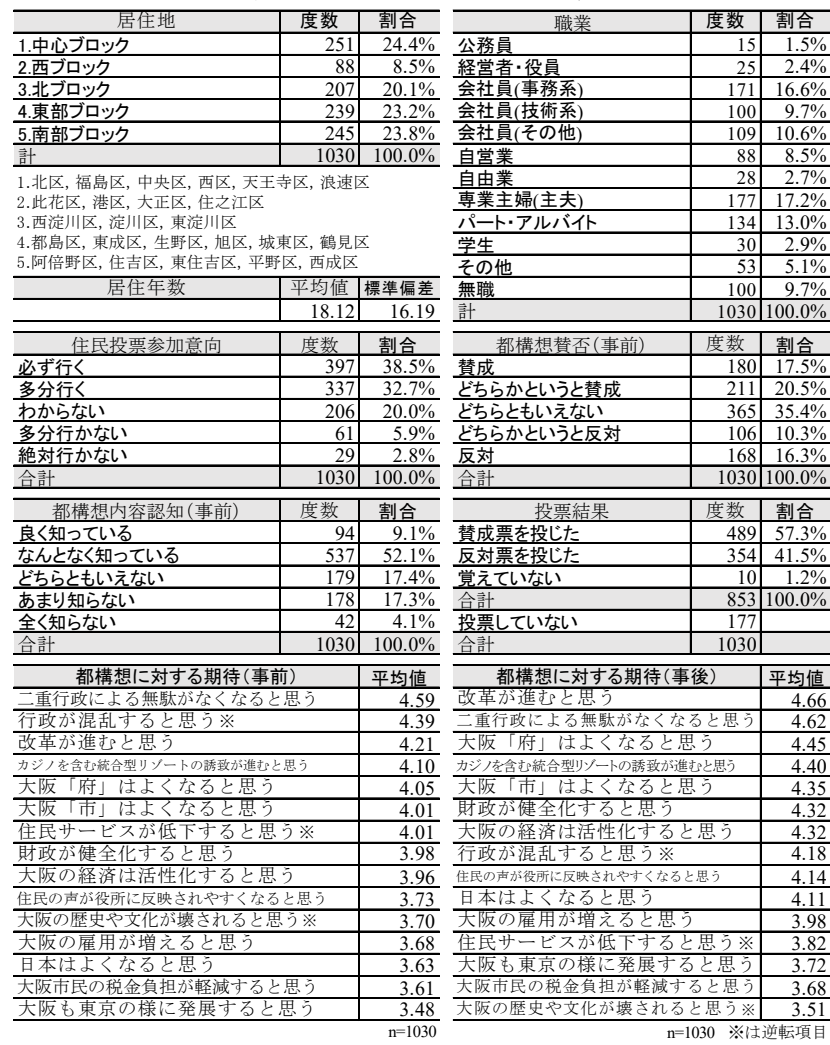




\section{g) 投票結果 (事後)}

都構想への賛否について「大阪都構想の住民投票で賛 成票を投じましたか，反対票を投じましたか?」という 質問を設定し，「賛成票を投じた」，「反対票を投じ た」,「覚えていない」の 3 段階で回答を要請した。 な お，別の問で都構想の投票の有無を尋ねており，1,030 サンプルの内，177 サンプルは「投票していない」との 回答であった.

\section{3. 分析結果}

\section{(1) 基本集計}

回答者属性及び各調查項目の集計結果を表-1 亿示す. 住民投票参加意志については，「必ず行く」，「多分行 く」を合わせると $71.3 \%$ 関心の高さがうかがえる．都 構想認知度についてみると，「なんとなく知っている」 が最も多く 52.1\%を占めているが「よく知っている」は $9.1 \%$ と 1 割に満たない，事前調査における都構想賛否は 「賛成」及び「どちらかというと賛成」を合わせると 38.0\%，「反対」及び「どちらかというと反対」を合わ せると $26.6 \%$ と賛成派が 1 割強高い，投票結果をみると， 「投票していない」と回答した 177 サンプルを除くと賛 成は $58.0 \%$, 反対が $42.0 \%$ と 2 割弱賛成が多くなってい る.なお，事前調查を実施した 2 月に近い 3 月の産経新 聞社による電話世論調査では反対は $47.5 \%$ ，賛成が 36.7\%であり 9，事前調査の結果とは異なる．また，住民 投票結果についても前述のとおり，本事後調査と賛否割 合は異なる.こうした違いは, 本調查はインターネット ユーザーを，世論調查は固定電話を有する世帯を対象と した抽出調査であることによる属性の違いが影響してい るものと考えられる．その意味で住民投票は民主主義に おける政治的プロセスの中で直接的に民意を捉える手段 として重要な役割を担うものと考えられる.

都構想に対する期待感の平均值を算出すると，住民投 票前調査においては，「二重行政による無駄がなくなる と思う」が最も高い一方で，逆転項目として尋㸚た「行 政が混乱すると思う」が二番目に高い值を示している. 一方，住民投票後調査においては，「改革が進むと思う」 が最も高く, 次いで,「二重行政による無駄がなくなる と思う」が高くなっている.

\section{（2）住民投票前後の賛否変化}

有権者が都構想に関して参考にした情報と政策判断と の関倸性についての分析に先立ち，住民投票前後の賛否 意識の変化から被験者を次のように分類する．即ち，投 票前調査において，「賛成」，「どちらかといえば賛 成」，「どちらともいえない」と回答していた一方で,
投票後調査において「反対票を投じた」と回答した群を 「否定的変化群」，投票前調査において，「反対」， 「どちらかといえば反対」，「どちらともいえない」と 回答していた一方で，投票後調査において「賛成票を投 じた」と回答した群を「肯定的変化群」とする. 肯定的 変化群は 168 件, 否定的変化群が 137 件であった. 以下 の分析は，両群のサンプルを抽出して行う.

\section{（3）各種情報の参照の程度と賛否変化に関する分析}

有権者が都構想に関して参考にした各種情報媒体が, 賛否判断に影響を及ぼしていたかを統計的に検証するた めに, 肯定的変化群及び否定的変化群における, 各種情 報媒体を参考にする程度の平均值の差の $\mathrm{t}$ 検定を行った。 なお，各種情報媒体を参考にする程度は，2.(2)fににて述 べたように，順序尺度で与えられおり，分析にはこの值 を用いた，結果を表-2及び図-1 に示す，まず，各種メデ イアの中でとりわけ参考にされている程度が高い媒体は 肯定的変化群, 否定的変化群ともにテレビとインターネ ットであることがわかる。一方で，いずれの媒体ともに 肯定的変化群, 否定的変化群との間に有意な差はみられ ない，一方，肯定的変化群が参考にしている傾向が高い 媒体は「橋下徹氏の Twitter」であることが示された。一 方, 否定的変化群が参考にしている傾向が高いメディア は「都構想の「効果」を主張する学者や専門家の意見」, 「都構想の「危険性」を指摘する学者や専門家の意見」, 「都構想の「効果」を主張するチラシ」，「都構想の 「危険性」を指摘するチラシ」であることがわかる。

\section{（4）各種情報の参照の程度と都構想に対する期待感の 変化に関する分析}

ここで，上述のように特定の情報の参考の程度が賛否 変化に影響を及ぼしている要因としては，当該情報への 接触を通じて, 都構想に対する期待感が変化したという 可能性が考えられる. そこで，上述のとおり，賛否変化 に影響を及ぼした可能性が示唆された情報媒体，即ち，

「都構想の「危険性」を指摘するチラシ」，「都構想の 「効果」を主張する学者や専門家の意見」，「都構想の 「効果」を主張するチラシ」，「橋下徹氏の Twitter」に つい, 否定的変化群, 肯定的変化群別に, 各情報媒体 を参考にする程度と，住民投票前後における都構想に対 する各種の期待感の変化量との相関分析を行った. ここ で，期待感の変化量とは，2.(2)d にて述べた都構想に対 する期待に関する各設問に対して肯定的な回答が高い得 点となるよう 7 点〜 1 点を割付け，事前事後の差を算出 したものである. その結果，表-3に示寸とおり，「肯定 的変化群」においては，いずれの媒体においても，それ らを参考にする程度と, 期待感の変化量との有意な相関 関係は見られなかった。 
表-2 「都構想の賛否変化」別の「都構想に関する各種情報媒体の参考の程度」の平均值の差の検定

\begin{tabular}{|c|c|c|c|c|c|c|c|}
\hline & 参考媒体 & グループ & 平均值 & 標淮偏美 & $T$ & $p$ & \\
\hline \multirow{13}{*}{$\begin{array}{l}\text { 肯 } \\
\text { 定 } \\
\text { 的 } \\
\text { 情 } \\
\text { 報 } \\
\text { 発 } \\
\text { 信 } \\
\text { 媒 } \\
\text { 体 }\end{array}$} & \multirow[t]{2}{*}{ (大阪市が主催する)住民説明会 } & 肯定的変化群 & 1.42 & 0.96 & \multirow{2}{*}{-0.06} & \multirow{2}{*}{\multicolumn{2}{|c|}{0.953}} \\
\hline & & 否定的変化群 & 1.42 & 1.00 & & & \\
\hline & \multirow{2}{*}{ タウンミーティング } & 肯定的変化群 & 1.39 & 0.91 & \multirow{2}{*}{0.19} & \multirow{2}{*}{\multicolumn{2}{|c|}{0.846}} \\
\hline & & 否定的変化群 & 1.37 & 0.94 & & & \\
\hline & \multirow{2}{*}{ 維新の会のホームページ } & 肯定的変化群 & 1.49 & 1.02 & \multirow{2}{*}{0.04} & \multirow{2}{*}{\multicolumn{2}{|c|}{0.966}} \\
\hline & & 否定的変化群 & 1.49 & 1.04 & & & \\
\hline & \multirow{2}{*}{ 橋下徹氏の街頭演説 } & 肯定的変化群 & 1.68 & 1.22 & \multirow{2}{*}{1.30} & \multirow{2}{*}{\multicolumn{2}{|c|}{0.193}} \\
\hline & & 否定的変化群 & 1.52 & 1.01 & & & \\
\hline & \multirow{2}{*}{ 橋下徹氏のテレビ出演 } & 肯定的変化群 & 2.10 & 1.42 & \multirow{2}{*}{1.33} & \multirow{2}{*}{\multicolumn{2}{|c|}{0.183}} \\
\hline & & 否定的変化群 & 1.90 & 1.24 & & & \\
\hline & \multirow{2}{*}{ 橋下徹氏の Twitter } & 肯定的変化群 & 1.44 & 0.98 & \multirow{2}{*}{2.69} & \multirow{2}{*}{\multicolumn{2}{|c|}{$0.008 * *$}} \\
\hline & & 否定的変化群 & 1.19 & 0.64 & & & \\
\hline & 都構想の|効果」を主張する学者や & 肯定的変化群 & 1.99 & 1.26 & \multirow{2}{*}{-2.00} & \multirow{2}{*}{\multicolumn{2}{|c|}{$0.047 *$}} \\
\hline & 専門家の意見 & 否定的変化群 & 2.31 & 1.43 & & & \\
\hline & 都構想の「効果」を主張するチラシ & 肯定的変化群 & 2.17 & 1.30 & -232 & 0.021 & \\
\hline & 都棤相 & 否定的変化群 & 2.53 & 1.39 & & & \\
\hline 信情否 & 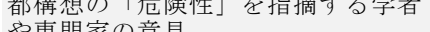 & 肯定的変化群 & 1.92 & 1.22 & -261 & 0010 & $* *$ \\
\hline 媒報 定 & 都構想の|息倇険性」を指摘するチラ & 否定的変化群 & 2.33 & 1.45 & & 0.010 & 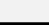 \\
\hline 体発的 & 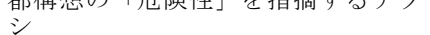 & 肯定的変化群 & 2.10 & 1.27 & -2.63 & 0.009 & $* * *$ \\
\hline & 詰士新間 & 肯定的変化群 & 1.63 & $\frac{1.40}{1.10}$ & & & \\
\hline & 院完新聞 & 否定的変化群 & 1.42 & 0.95 & 1.77 & 0.078 & \\
\hline & 朝日新聞 & 肯定的変化群 & 1.57 & 0.99 & 0.65 & 0510 & \\
\hline & & 否定的変化群 & 1.50 & 1.03 & 0.05 & 0.519 & \\
\hline & 毎日新聞 & 肯定的変化群 & 1.46 & 0.94 & 102 & 0.310 & \\
\hline & & 否定的変化群 & 1.36 & 0.87 & & & \\
\hline & 日本経済新聞 & 肯定的変化群 & 1.40 & 0.90 & 091 & 0361 & \\
\hline & & 否定的変化群 & 1.31 & 0.81 & 0.91 & 0.361 & \\
\hline & 産経新聞 & 肯定的変化群 & 1.46 & 1.00 & 0.57 & 0.571 & \\
\hline $\begin{array}{l}\text { 问 } \\
==0\end{array}$ & & 否定的変化群 & 1.39 & 0.97 & & & \\
\hline 論 & 地方紙 & 肯定的変化群 & 1.23 & 0.64 & 010 & 0.846 & \\
\hline 発 & & 否定的変化群 & 1.24 & 0.68 & -0.19 & 0.840 & \\
\hline 信 & スポーツ新聞 & 肯定的変化群 & 1.26 & 0.67 & 1.38 & 0168 & \\
\hline 媒 & & 否定的変化群 & 1.16 & 0.53 & 1.38 & & \\
\hline 体 & 调刊䚾 & 肯定的変化群 & 1.25 & 0.65 & 041 & 0680 & \\
\hline & 退门訫 & 否定的変化群 & 1.22 & 0.65 & 0.41 & 0.080 & \\
\hline & テレド & 肯定的変化群 & 3.29 & 1.23 & 057 & 0571 & \\
\hline & & 否定的変化群 & 3.21 & 1.23 & 0.57 & $0.5 / 1$ & \\
\hline & インターネッ卜 & 肯定的変化群 & 2.93 & 1.38 & 115 & 0251 & \\
\hline & & 否定的変化群 & 2.74 & 1.49 & 1.15 & 0.251 & \\
\hline & 書籍 & 肯定的変化群 & 1.29 & 0.75 & 016 & 0872 & \\
\hline & & 否定的変化群 & 1.28 & 0.80 & 0.16 & $0.8 / 2$ & \\
\hline & 周囲の人の音貝 & 肯定的変化群 & 2.18 & 1.26 & -176 & 0.079 & \\
\hline & & 否定的変化群 & 2.45 & 1.38 & $-1 . / 6$ & $0.0 / 9$ & \\
\hline
\end{tabular}

肯定的変化群 $\mathrm{n}=168$, 否定的変化群 $\mathrm{n}=137$

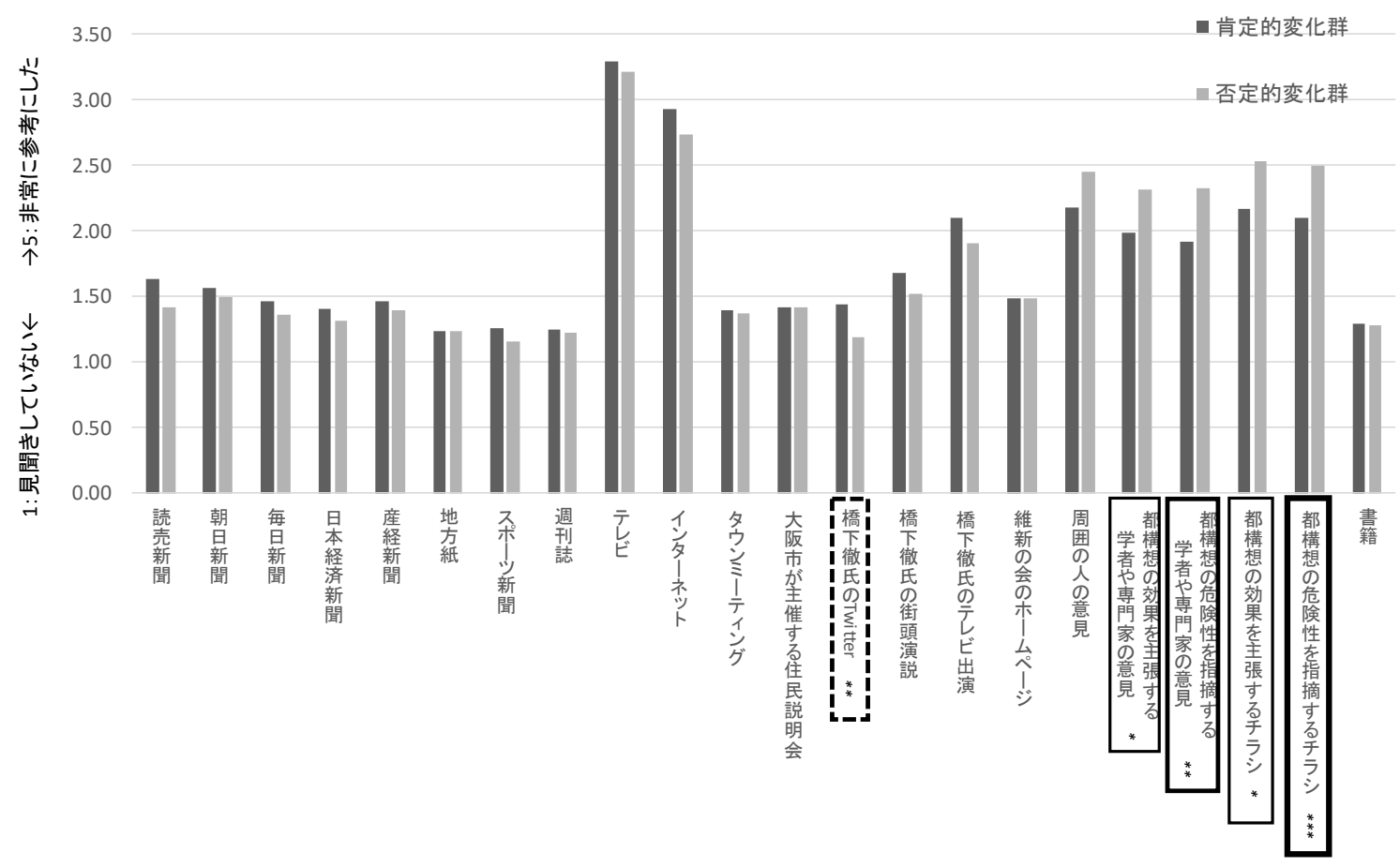

I--ーI : 肯定的変化群の方が有意に強く参考にした（=そのメディアで肯定的に変化した）

: 否定的変化群の方が有意に強く参考にした（=そのメディアで否定的に変化した）， ${ }^{*} \mathrm{p}<.05 \quad * * \mathrm{p}<.01 \quad * * * \mathrm{p}<.001$

図-1「都構想の賛否変化」別の「都構想に関する各種情報媒体の参考の程度」の平均值 
表-3「都構想に関する各種情報媒体の参考の程度」と「住民投票前後の都構想期待感の変化量」との相関係数

\begin{tabular}{|c|c|c|c|c|c|c|c|c|c|c|c|c|c|c|c|c|c|}
\hline & & & $\begin{array}{l}\text { 大阪 } \\
\text { 「府」は } \\
\text { よくなる } \\
\text { と思う }\end{array}$ & $\begin{array}{l}\text { 大阪 } \\
「 \text { 市」は } \\
\text { よくなる } \\
\text { と思う }\end{array}$ & $\begin{array}{l}\text { 日本はよ } \\
\text { くなると } \\
\text { 思う }\end{array}$ & $\begin{array}{l}\text { 大阪の雇 } \\
\text { 用が壃え } \\
\text { ると思う }\end{array}$ & $\begin{array}{l}\text { 大阪の経 } \\
\text { 済は活性 } \\
\text { 化すると } \\
\text { 思う }\end{array}$ & $\begin{array}{l}\text { 二重行政 } \\
\text { によるる無 } \\
\text { 駄がなく } \\
\text { なると思 } \\
\text { う }\end{array}$ & $\begin{array}{l}\text { 住民の声 } \\
\text { が役所に } \\
\text { 反映され } \\
\text { やすくな } \\
\text { ると思う }\end{array}$ & $\begin{array}{l}\text { 大阪市民 } \\
\text { の税金負 } \\
\text { 担が軽減 } \\
\text { すると思 } \\
\text { う }\end{array}$ & $\begin{array}{l}\text { 行政が混 } \\
\text { 乱すると } \\
\text { 思う※ }\end{array}$ & $\begin{array}{l}\text { 住民サー } \\
\text { ビスがス低 } \\
\text { 下すると } \\
\text { 思う※ }\end{array}$ & $\begin{array}{l}\text { 財政が健 } \\
\text { 全化する } \\
\text { と思う }\end{array}$ & $\begin{array}{l}\text { 大阪も東 } \\
\text { 京の様に } \\
\text { 発展する } \\
\text { と思う }\end{array}$ & $\begin{array}{l}\text { 改革が進 } \\
\text { むと思う }\end{array}$ & $\begin{array}{l}\text { 大阪の糜 } \\
\text { 史や文化 } \\
\text { が買され } \\
\text { ると思う } \\
\text { ※ } \\
\end{array}$ & $\begin{array}{l}\text { カジノを } \\
\text { 含む統合 } \\
\text { 型りゾー } \\
\text { トの誘致 } \\
\text { が䍜むと } \\
\text { 思う } \\
\end{array}$ \\
\hline \multirow{10}{*}{$\begin{array}{l}\text { 肯 } \\
\text { 定 } \\
\text { 的 } \\
\text { 変 } \\
\text { 化 } \\
\text { 群 }\end{array}$} & \multirow{2}{*}{\multicolumn{2}{|c|}{$\begin{array}{l}\text { 都構想の「危険 } \mathrm{r} \\
\text { 情を摘する } \\
\text { 学者や尃門家の } \mathrm{p} \\
\text { 意見 }\end{array}$}} & .050 & .063 & .055 & .069 & .076 & .055 & -.032 & -.039 & -.031 & .073 & .091 & .012 & .131 & -.006 & .067 \\
\hline & & & .522 & .416 & .476 & .375 & .326 & .480 & .684 & .612 & .686 & .348 & .240 & .879 & .091 & .939 & .391 \\
\hline & \multirow{2}{*}{\multicolumn{2}{|c|}{$\begin{array}{l}\text { 都構想の「危険 } \mathrm{r} \\
\text { 性」を指摘する } \\
\text { チラシ } \mathrm{p}\end{array}$}} & .085 & -.033 & .020 & .105 & .131 & .042 & .040 & -.046 & -.048 & -.008 & .052 & .010 & .110 & -.019 & .032 \\
\hline & & & .274 & .668 & .794 & .174 & .092 & .590 & .609 & .550 & .537 & .922 & .506 & .898 & .154 & .803 & .679 \\
\hline & \multirow{2}{*}{$\begin{array}{l}\text { 都構想の「効 } \\
\text { 果」を主張する } \\
\text { 学者や専門家の } \\
\text { 意見 }\end{array}$} & & .027 & .092 & .093 & .065 & .084 & .026 & -.028 & -.064 & -.052 & .090 & .071 & .019 & .143 & -.034 & .070 \\
\hline & & $\mathrm{p}$ & .732 & .238 & .230 & .403 & .281 & .741 & .715 & .411 & .506 & .244 & .363 & .807 & .065 & .662 & .364 \\
\hline & $\begin{array}{l}\text { 都構想の「効 } \\
\text { 主張する果 }\end{array}$ & $\mathrm{r}$ & .066 & -.026 & .065 & .061 & . 109 & .058 & -.020 & -.090 & -.009 & .012 & .060 & -.013 & .131 & . 009 & . 060 \\
\hline & チラシ & $\mathrm{p}$ & .396 & .735 & .400 & .430 & .161 & .455 & .792 & .245 & .906 & .880 & .441 & .864 & .090 & .905 & .443 \\
\hline & 橋下徹氏の & $\mathrm{r}$ & .011 & -.021 & .094 & .111 & .033 & .046 & -.017 & .099 & .055 & .010 & .020 & -.026 & -.039 & -.003 & .059 \\
\hline & & $\mathrm{p}$ & .890 & .783 & .224 & .151 & .668 & .554 & .828 & .202 & .477 & .899 & .801 & .741 & .618 & .967 & .451 \\
\hline \multirow{10}{*}{$\begin{array}{l}\text { 否 } \\
\text { 定 } \\
\text { 的 } \\
\text { 変 } \\
\text { 化 } \\
\text { 群 }\end{array}$} & \multirow{2}{*}{\multicolumn{2}{|c|}{$\begin{array}{l}\text { 都構想の「危険 } \mathrm{r} \\
\text { 恉摘する } \\
\text { 学者や尃門家の } \mathrm{p} \\
\text { 意見 }\end{array}$}} & -.065 & -.158 & .044 & .006 & .143 & -.085 & .097 & -.047 & .105 & .100 & $-.229^{* *}$ & -.124 & -.088 & .099 & .032 \\
\hline & & & .452 & .065 & .609 & .949 & .094 & .322 & .262 & .587 & .224 & .246 & .007 & .150 & .307 & .251 & .706 \\
\hline & \multirow{2}{*}{\multicolumn{2}{|c|}{$\begin{array}{l}\text { 都構想の「危険 } \mathrm{r} \\
\text { 性」を指摘する } \\
\text { チラシ }\end{array}$}} & -.096 & -.137 & -.034 & -.009 & .043 & -.099 & .027 & -.085 & .029 & .112 & $-.256^{* *}$ & -.119 & -.123 & .043 & $.184^{*}$ \\
\hline & & & .267 & .111 & .692 & .918 & .619 & .251 & .753 & .326 & .735 & .192 & .003 & .165 & .151 & .615 & .031 \\
\hline & \multirow{2}{*}{$\begin{array}{l}\text { 都構想の「効 } \\
\text { 果」を主張する } \\
\text { 掌者や尃門家の } \\
\end{array}$} & & -.063 & -.119 & .059 & .054 & .165 & -.061 & .156 & -.033 & .052 & .051 & $-.196^{*}$ & -.081 & -.033 & .076 & -.012 \\
\hline & & $\mathrm{p}$ & .461 & .165 & .497 & .530 & .055 & .482 & .069 & .705 & .549 & .550 & .022 & .349 & .705 & .375 & .889 \\
\hline & $\begin{array}{l}\text { 都構想の「効 } \\
\text { 果」を主張する }\end{array}$ & r & -.016 & -.079 & .093 & .073 & .087 & -.052 & .097 & -.038 & -.066 & .039 & $-.214^{*}$ & -.023 & -.038 & -.036 & .053 \\
\hline & チラシ & $\mathrm{p}$ & .856 & .361 & .278 & .397 & .314 & .545 & .258 & .660 & .445 & .654 & .012 & .791 & .656 & .675 & .541 \\
\hline & & $\mathrm{r}$ & .121 & .050 & $.238^{* *}$ & $.258^{* *}$ & $.211^{*}$ & .082 & .095 & -.013 & .075 & -.072 & -.162 & .043 & .130 & $-.178^{*}$ & -.040 \\
\hline & Twitter & $\mathrm{p}$ & .160 & .562 & .005 & .002 & .013 & .338 & .272 & .878 & .386 & .402 & .058 & .622 & .129 & .037 & .641 \\
\hline
\end{tabular}

一方，「否定的変化群」に着目寸ると，「都構想の 「危険性」を指摘する学者や専門家の意見」，「都構想 の「危険性」を指摘するチラシ」に加え, 都構想の「効 果」を主張する学者や専門家の意見」，「都構想の「効 果」を主張するチラシ」においても，各情報媒体を参考 にする程度が高いほど, 都構想によって「財政が健全化 する」という期待感が低減している傾向が確認された.

また，「都構想の「危険性」を指摘するチラシ」を参考 にする程度と「カジノを含む統合型リゾーh y 下の誘致 が進むと思う」との間には正の相関がみられる。これは, 当該設問は，都構想に対する期待感として尋ねたもので あるが，否定的変化群においては，この「カジノを含む 統合型リゾートの誘致」が，期待感ではなく，危険性と して捉えられた可能性があり，そのために，正の相関と なっている可能性が考えられる. 一方, 「否定的変化群」 において，「橋下徹氏の Twitter」を参考にする程度が高 いほど，「日本はよくなると思う」，「大阪の雇用が増 えると思う」，「大阪の経済は活性化すると思う」とい う期待感が増加していることに加えて, 逆転項目として 尋ねた「大阪の歴史や文化が壊されると思う」は低下し ている傾向が確認された（なお，これらの有意な相関が 見られた変数ペアの散布図を確認したところ, 否定的変 化群における「橋下徹氏の Twitter」を含む变数ぺアの有
意な相関は特異值の影響で見られたものである一方，そ れ以外の有意な変数ぺアについてはそうした特異值の影 響は見られなかった。 それ故, 否定的変化群における 「橋下徹氏の Twitter」を含む変数ペアが統計的に連関し ていると判断することは困難であることが示された. 詳 細は付録[1]を参照されたい）。

\section{（5）＼cjkstart各種情報の参照の程度と各種情報への評価}

次に，賛否変化に影響があった各種情報媒体の参考の 程度と, 都構想に関する情報の評価の関係性を確認する ための相関分析を行った. 結果を表-4に示す. まず，肯 定的変化群に着目すると，いずれの情報媒体においても, 各媒体を参考にする程度と「大阪都構想に関するメディ アの報道は偏っていたと思う」との間に正の相関がみら れる.さらに「橋下徹氏の Twitter」を参考にする程度が 高いほど，「大阪都構想の反対派は，デマばかり言って いた」という心的傾向が高いことが確認された. 一方, 否定的変化群に着目すると，「橋下徹氏の Twitter」を参 考にする程度が高いほど，「大阪都構想の賛成派は，デ マばかり言っていた」という心的傾向が高いことが確認 された。 
表-4「都構想想に関する各種情報媒体の参考の程度」と「都構想に関する情報の評価」との相関係数

\begin{tabular}{|c|c|c|c|c|c|}
\hline & & & $\begin{array}{l}\text { 大阪都構想に関する } \\
\text { メディアの報道は } \\
\text { 偏っていたと思う }\end{array}$ & $\begin{array}{l}\text { 大阪都構想の反対派は, } \\
\text { デマばかり言っていた }\end{array}$ & $\begin{array}{l}\text { 大阪都構想の賛成派は, } \\
\text { デマばかり言っていた }\end{array}$ \\
\hline \multirow{10}{*}{$\begin{array}{l}\text { 肯 } \\
\text { 定 } \\
\text { 的 } \\
\text { 変 } \\
\text { 化 } \\
\text { 群 }\end{array}$} & \multirow{2}{*}{$\begin{array}{l}\text { 都構想の } \\
\text { 「危険性」を指摘する学者や専門 } \\
\text { 家の意見 }\end{array}$} & $\mathrm{r}$ & $.185^{*}$ & .026 & -.064 \\
\hline & & $\mathrm{p}$ & .017 & .735 & .408 \\
\hline & \multirow{2}{*}{$\begin{array}{l}\text { 都構想の } \\
\text { 「危険性」を指摘するチラシ }\end{array}$} & $\mathrm{r}$ & $.191 *$ & -.034 & -.011 \\
\hline & & $\mathrm{p}$ & .013 & .659 & .888 \\
\hline & \multirow{2}{*}{$\begin{array}{l}\text { 都構想の } \\
\text { 「効果」を主張する学者や専門家 } \\
\text { の意見 }\end{array}$} & $\mathrm{r}$ & $.197^{*}$ & .060 & -.110 \\
\hline & & $\mathrm{p}$ & .010 & .439 & .155 \\
\hline & \multirow{2}{*}{$\begin{array}{l}\text { 都構想の } \\
\text { 「効果」を主張するチラシ } \\
\end{array}$} & $\mathrm{r}$ & $.229 * *$ & -.021 & -.045 \\
\hline & & $\mathrm{p}$ & .003 & .790 & .559 \\
\hline & \multirow{2}{*}{ 橋下徹氏のTwitter } & $\mathrm{r}$ & $.162 *$ & $.163 *$ & .017 \\
\hline & & $\mathrm{p}$ & .036 & .035 & .823 \\
\hline \multirow{10}{*}{$\begin{array}{l}\text { 否 } \\
\text { 定 } \\
\text { 的 } \\
\text { 変 } \\
\text { 化 } \\
\text { 群 }\end{array}$} & \multirow{2}{*}{$\begin{array}{l}\text { 都構想の } \\
\text { 「危険性」を指摘する学者や専門 } \\
\text { 家の意見 }\end{array}$} & $\mathrm{r}$ & .041 & .023 & -.048 \\
\hline & & $\mathrm{p}$ & .632 & .792 & .579 \\
\hline & \multirow{2}{*}{$\begin{array}{l}\text { 都構想の } \\
\text { 「危険性」を指摘するチラシ }\end{array}$} & $\mathrm{r}$ & -.097 & .074 & .000 \\
\hline & & $\mathrm{p}$ & .260 & .393 & .999 \\
\hline & \multirow{2}{*}{$\begin{array}{l}\text { 都構想の } \\
\text { 「効果」を主張する学者や専門家 } \\
\text { の意見 }\end{array}$} & $\mathrm{r}$ & -.009 & .031 & -.112 \\
\hline & & $\mathrm{p}$ & .916 & .716 & .193 \\
\hline & \multirow{2}{*}{$\begin{array}{l}\text { 都構想の } \\
\text { 「効果」を主張するチラシ }\end{array}$} & $\mathrm{r}$ & -.155 & -.063 & -.132 \\
\hline & & $\mathrm{p}$ & .070 & .462 & .124 \\
\hline & \multirow{2}{*}{ 橋下徹氏のTwitter } & $\mathrm{r}$ & .028 & .070 & $.173 *$ \\
\hline & & $\mathrm{p}$ & .744 & .416 & .043 \\
\hline
\end{tabular}

肯定的変化群 $\mathrm{n}=168$, 否定的変化群 $\mathrm{n}=137$

\section{4. 考察}

\section{（1）各情報の特徵}

各種情報媒体が都構想に対する賛否意識に及ぼした影 響を考察するにあたり，まず，以下の根拠に基づき，各 情報媒体をその主張内容に基づき，「肯定的情報発信媒 体」「否定的情報発信媒体」「両論発信媒体」の3 種に 分類する.

まず，「肯定的情報発信媒体」について，橋下市長は 自身のツイッター10)において，「大阪市は大阪都構想を 市の方針としたのだから，その提案理由，必要性を述べ るのは当然だ。大阪市が何かの政策をやろうと思えば, その理由と必要性を述べる，場合によっては住民説明会 を開く．当然税金で説明会を開く．住民の皆さんに納得 してもらうために，提案理由を丁寧に説明する.」と述 ベているように，市が主催する住民投票や，橋下氏の都 構想に関する発言は，「二重行政の解消」や「住民サ一 ビスの充実」といった都構想による効果を訴える主張や その主張を後押しするための情報が大半を占めることか ら，「(大阪市が主催する)住民説明会」，「橋下徹氏の 街頭演説」，「橋下徹氏のテレビ出演」，「橋下徹氏の Twitter」を「肯定的情報発信媒体」に位置付けた。また， 大阪維新の会は，大阪都構想を改革の「一丁目一番地」 として最重要政策に位置づけており，同党による「タウ ンミーティング」や「維新の会のホームページ」におい て，パネルや動画を用いてその効果を様々な観点から主
張していることから，両者もまた，「肯定的情報発信媒 体」に位置付けた.さらに，「都構想の「効果」を主張 する学者や専門家の意見」及び「都構想の「効果」を主 張するチラシ」は，文字通り「肯定的情報発信媒体」で あり，その具体例として，前者については，高橋洋一嘉 悦大学教授 (大阪市特別顧問) や，佐々木信夫中央大学 教授（2015年 3 月末まで大阪市特別顧問）によるインタ 一ネット記事が想定される. 後者については, 維新の会 が発行する広報誌「維新プレス」などが考えられる.

次に，「否定的情報発信媒体」については，「都構想 の「危険性」を主張する学者や専門家の意見」，「都構 想の「危険性」を主張するチラシ」が該当する. その情 報源は特定できないものの，前者の候補としては，教育 学, 政治学, 防災学，行政学等の多様な分野にまたがる 複数の専門家による「『大阪都構想』の危険性を明らか にする学者記者会見」, 後者については, 都構想の反対 派である自民党や共産党の広報誌が挙げられる.

最後に，「両論発信媒体」について，国内の新聞やテ レビにおける報道は，一つの意見が主流であっても，も う一方の，あるいは対立する意見についても取材報道す る両論併記が原則とされており，特に，政策や特定の意 思などを決定する過程において，ある一つの意見ではな く，複数の意見や見解について取材報告していくのが一 般的とされる ${ }^{11)}$. また，テレビの場合は，放送法で「多 角的論点提示」に務めるよう定められていることから， 読売新聞をはじめとする各種「新聞・週刊誌」及び「テ 
レビ」を「両論発信媒体」として位置づけた. 加えて, 「インターネット」，「書籍」には，肯定的，否定的， 中立的と多様な意見が存在している.「周囲の人の意見」 も表-2に示したように，世論が二分していることから， 「両論発信媒体」として位置づけた。都構想は，大阪市 を廃止し，大阪市域に新たに 5 つの特別区を設置するも のであり，住民自治の在り方，また，行政運営に極めて 重要な変化をもたらす大改革といえる. したがって，そ の実施の是非を巡る判断は，感情や心理的動機ではなく, 当該政策が如何なる影響を及ぼすか，という客観的検証 に基づく理性的判断が下されねばならない，一方で，都 構想を巡っては，そうした理性的判断を困難にする相反 する情報が，連日，政治家や学者，専門家等によって発 信された，例えば，賛成派である維新の会のホームペー ジには，「二重行政による「お金のムダ」は膨大な額 （1 兆円以上数兆円）にのぼります」と記載されている ${ }^{12}$ 一方で, 反対を主張寸る日本共産党のホームページ13に おいては，「「4000億円が浮く」は大ウソ，大きな財源 不足に！」と記載されている.この両者の意見の相違に 関しては, 後に, 日本経済新聞によって,「（二重行政 解消の効果には）都構想の実現とは関係の無い項目」も 加えられており，それらを差し引いた財政効果は年間約 1 億円にしか過ぎないことが，大阪市役所の推計值とし て議会報告されたという事実が報じられている ${ }^{14)}$. しか しながら，仮に，有権者が上記のケースにおいて，こう した報道に触れることがなければ，一方の主張が事実に 反している場合においても，その主張が「事実」である か否かを専門的知識を有さない一般市民が見極めること は，必ずしも容易ではないものと考えられる．実際に,

表-2及び図-1 に示したように，新聞やテレビをはじめと する「両論併記」に位置付けた媒体は，いずれも賛否判 断の変化に影響を及ぼしていなかった様子がみてとれる.

\section{（2）政策の賛否に対する判断基準}

一方で，そうした両論に触れながらも，理性的な判断 を下している有権者の存在を示唆するデータがある.

表-2 及び図-1によると「否定的変化群」は，「肯定的 変化群」よりも，「否定的情報発信媒体」である「都構 想の「危険性」を主張する学者や専門家の意見」及び

「チラシ」に加え, 「肯定的情報発信媒体」である「都 構想の「効果」を主張する学者や専門家の意見」及び 「チラシ」を参考にしている傾向が高いことがわかる. このことは, 否定的変化群においては, 都構想に対する 否定的，肯定的双方の情報を得た上で，否定的な情報に 対して，より正当性を見出した，あるいは，肯定的情報 に対して，より懐疑的になった，あるいはその両方によ って，反対に転じた可能性を示唆するものである．この
点について, 表-3からは, 否定的変化群において, 「効 果」を主張する学者や専門家の意見やチラシといった都 構想に対する肯定的情報に触れているほど, それに反し て，「財政が健全化する」という都構想による期待感が 低減していることが分かる.

一方, 肯定的変化群においては, 肯定的な論調の情報 媒体に位置付けた情報媒体の中で, 唯一, 意見を肯定的 に変化させる力を有していたのが「橋下徹氏の Twitter」 であった可能性が示された。ついて，この「橋下徹氏 の Twitter」に着目寸ると，表-3 の否定的変化群に関する 個所に示したように，「橋下徹氏の Twitter」の参考の程 度と, 都構想による各種の期待感の事前事後の変化量に は, いずれも有意な相関関係は見られなかった一方で,

表-4に示すように，「橋下徹氏の Twitter」の参考の程度 と「大阪都構想に関するメディアの報道は偏っていたと 思う」，「大阪都構想の反対派は，デマばかり言ってい た」との間に有意に正の相関がみられた. すなわち,

「橋下徹氏の Twitter」は, 少なくとも本研究で調査項目 として挙げた「都構想による種々の期待感」を増進させ る効果を有してはいなかった一方で，メディアの報道が 偏っている，反対派の主張が「デマである」という効果 を持っていたのである【2!

これらをまとめて考えれば，橋下徹氏の Twitterによっ て大阪都構想に対する態度を肯定的なものに変える力を 持っていたのは, 橋下徹氏の Twitterによって大阪都構想 の「中身」についての「期待」「認識」を「変容」させ たためではなく，マスメディアの報道も「反対派」の主 張も間違っているという風に思わしめたが故である, と いう可能性が考えられる.

なお，以上の結果を「説得」に関する心理学における 精緻化見込みモデル (Elaboration Likelihood Model : ELM) に基づけば，次のように解釈することができる，ELM は, Petty \& Cacioppo ${ }^{15)}$ により提唱されたモデルであり， 手がかり, 精緻化見込みの程度, ルートという概念を用 いて人々が意思決定を行う際の情報処理過程を説明する. ここでの手がかりとは，判断に用いる情報のことであり， 情報の種類によって中心的手がかりと周辺的手がかりに 区別される. 中心的手がかりは議論や説得内容そのもの を指し, 周辺的手がかりは中心的手がかり以外の情報, すなわち議論や説得内容以外の情報を指寸，精緻化見込 みの程度は，人々が対象に関連する情報について考え， 評価する能力と動機づけの程度を指す. 説得を受け入れ るかどうかの意思決定において，内容という中心的手が かりを精緻に吟味することによる「中心的ルート」，あ るいは情報源の信憑性など内容以外の周辺的手がかりに 基づくヒューリスティックな判断による「周辺的ルート」 の 2 つの情報処理方略を仮定する.メッセージの受け手 
である被説得者がこのどちらの情報処理方略を用いるの かは，精緻化見込みの程度によって決まる。この精緻化 見込みの程度は能力と動機付けの状態による. それぞれ 能力と動機づけを高い場合と低い場合に区別し，能力と 動機付けがともに高い場合を精緻化の見込みが高い状態, 能力と動機付けのどちらか一方，あるいは両者が低い場 合を精緻化見込みが低い状態とする，精緻化見込みが高 い場合には，人々が「中心的ルート」，才なわち中心的 手がかりを吟味することによって判断を行い，一方で精 緻化見込みが低い場合には，人々が「周辺的ルート」， すなわち周辺的手がかりに基づいて判断を行う. 本研究 のケースにおける「中心的ルート」とは, 大阪都構想の 「中身」についての情報に触れる判断を行うルートであ る. 一方「周辺ルート」とは, 態度を形成するにあたっ ての周辺的な情報, 例えば, 話者のイメージや話し方な ど，上記の中心的情報とは異なる，合理的態度形成にお いては必ずしも重要とは言いがたい手がかり情報に基づ いて判断を行うルートである ${ }^{19}$. 本研究では, 都構想の 「中身」ではなく，それについて情報を提供する人々の イメージ等がそれにあたる．この分類で考えると，態度 が肯定的に変化した人々（賛成するようになった人々） において参考にされた（本研究で確認できた）情報は, 中心的情報ではなく周辺的情報であった一方，それとは 逆に，否定的に変化した人々（反対するようになった 人々）において参考にされた（本研究で確認できた）情 報は周辺的情報ではなく中心的情報であったと解釈する ことができるであろう。なお，以上の議論はあくまでも， 本研究の調査データから得られた結論であるに過ぎず, 最終的な結論を下すにはさらなる調査, 分析が必要であ ることは論を待たない．

\section{5. おわりに}

本研究は都市計画，土木計画に抜本的な影響を及ぼす 地方政府の統治機構改革を決する政治プロセスの合理化 を図る上で，如何なるコミュニケーションの展開が効果 的であるのかについての実証的知見を得る事を目的とし て，昨今の統治機構改革の中でも，実現される可能性が 高い，大阪市を廃止して都区制度を導入する，いわゆる

「大阪都構想」を事例として, 有権者の接触メディアと 政策判断との関係性を分析した.

その結果，両論を示された場合は，いずれの情報が真 であるか，という理性的判断が困難となるが故に従前の 意見を変化させない可能性が示唆された一方で，そうし た状況においても，心理学における精緻化見込理論でい うところの「中心ルート」と呼ばれる認知的経路によっ て，いずれの情報により多くの正当性が認められるかを
判断した有権者はその危険性に目を向け，「反対」に転 じたことが示された。一方で, 感情的な口語表現と効率 性を重視したソーシャルメディア17の一つとされるツイ ッターをよく参考にした有権者は「賛成」に転じており， それは，政策に対する期待感の増進によるものではなく， 情報が偏っているという認識, 及び, 反対派の主張が事 実ではないという精緻化見込理論でいうところの「周辺 ルート」と呼ばれる認知的経路による態度変容であった という可能性が示唆された.

以上の結果は, 政策議論において, 両論が存在する以 上，両者の主張の中に，真偽に対する有権者の理性的な 判断を阻害する「事実ではない情報」あるいは，「事実 に関する認識をゆがめる情報」の存在が確認された場合 には，徹底的にそれを批判し，排除していくことの重要 性を改めて示すものである. 一方で, 周辺ルートでは, こうした「事実ではない情報」あるいは，「事実に関す る認識をゆがめる情報」をも, その他の情報と共に態度 形成の手がかりとしてしまうため, 中心ルートでの判断 よりも，後に禍根を残す必ずしも合理的とは言いがたい 判断が下される可能性もある. 今後, 適切な統治機構を 導く民主的判断を期するのなら, 可能な限り中心ルート での意見形成が成される事を企図した世論形成プロセス のあり方を研究する必要がある.

なお，繰り返しとなるが，本研究で得られた結果は， 本研究において分析可能な調査デー夕に基づくものであ り, 最終的な結論に向けてはさらなる実証分析が求めら れている. また, 本分析においては, 有権者が参考にし た各情報媒体の「具体的な内容」に基づく分析を行って いないため, 今後は本稿で割愛した「有権者が参考にし た情報の具体例」の自由記述に基づく詳細の分析が必要 と考えられる. 今後はこうした課題を一つずつ考慮しな がら，あらゆる政策についての賛否報告ではなく，虚偽 を排した事実に基づく情報を提供した上で，可能な限り 「周辺ルート」ではなく「中心ルート」での判断に基づ く世論形成の在り方を考えることが重要であると考えら れる.ここで，虚偽を排した事実情報の提供においては， 科学に深く係る論争において用いられている共同事実確 認（joint fact finding） 18)，すなわち，ほぼ全てのステーク ホルダーが納得できる科学的情報を, ステークホルダー と専門家の協働で特定する作業がその一助となり得るも のと考えらえる. そして，そうしたプロセスが実施され るためには，第一に事実情報が権力者によって統制され ることなく, 国民に広く公平に行き渡るための自由な言 論空間が確保されることが何よりも重要であることは言 うまでもない. また世論の変化速度についての知見を得 るためには，住民投票前後で「賛否に変化が見られなか った」人々も含めた検証が必要であると考えられる. 


\section{付録}

[1] 否定的変化群において，その投票判断に反して， 都構想に対する期待感が増加し, 否定的意識が低減して いる点について，表-3で有意な相関が示された否定的変 化群 137 サンプルを抽出し，有意な相関が示されたペア 全てのバブルチャート（プロットする点の数を円の大き さで表現した散布図の一種）を作成したところ，付表-1 に示すように，「橋下徹氏の Twitter」の参考の程度と， 都構想に対する期待感として尋ねた「日本はよくなると 思う」，「大阪の雇用が増えると思う」，「大阪の経済 は活性化すると思う」及び，「大阪の歴史や文化が壊さ れると思う」のそれぞれとの関係性を示した上段の $4 つ$ のグラフについては，他のグラフに見られない外れ值の 存在（「橋下徹氏の Twitter」を「少し参考にした」， 「非常に参考にした」と回答している被験者各 1名）が 確認された. なお, この外れ值を確認したところ, これ らはいずれも同一人物の回答であることが確認された. なお，この外れ值二名を削除した上で相関係数を求める と, いずれも有意とはならなかった（順に， $\mathrm{r}=.117$, $\mathrm{r}=.093, \mathrm{r}=.025, \mathrm{r}=-.138)$ ため, 「橋下徹氏の Twitter」に おいて見られた有意な相関係数は，この「二名」の回答 の影響によって有意となったとものと言うことができる.
相関分析や回帰分析においてはこうした特異值は削除し た上で，相関の有無を判断することが一般的である。な お，「橋下徹氏の Twitter」を含まない変数ぺアの有意な 相関においては，付図-1に示した通り，こうした外れ值 は確認されなかった. こうしたデータは，相関分析とい う統計的手続きで有意となった変数ペアの内，「橋下徹 氏の Twitter」が含まれる変数ペアにおいては有意な相関 が得られたものの，それはあくまでも見かけの上での相 関であって，実際上の相関が存在するとは判断しがたい ものと考えられる.

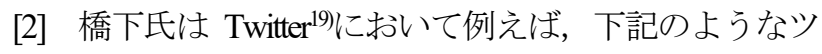
イートを行っており，短い文章の中で「デマ」や「バカ 学者」「嘘八百」といった感情的な口語表現を用いてい ることがわかる.「デマです．今まで大阪市役所がやっ ていた仕事を大阪都庁がやるだけ．お金は仕事と一体で す。お金だけが移ることはありません，国土強勒化を唱 える学者は勉強不足」,「バカな学者の典型です。学長 になって初めて大阪都構想の意味が分かるでしょう。」， 「大阪市民の税金が大阪市外に出ていくと騒いでいる内 閣参与のバカ学者は，大阪都構想の制度設計図を何も読 んでいません」，「それが地方行政のことを何も知らな いまま，とんでもない嘘八百を言っているので公開討論 を申し入れました.」

付表-1 事前事後における全調査項目

\begin{tabular}{|c|c|c|c|}
\hline & 事前調查項目 & & 事後調查項目 \\
\hline & 属性 & & 属性 \\
\hline a) & 都構想内容認知 & & 統一地方選の投票先と判断基準 \\
\hline b) & 住民投票参加意向 & & 都構想に対するイメージ \\
\hline c) & $\begin{array}{l}\text { 都構想賛否 } \\
\text { 都構想に対するイメージ }\end{array}$ & g) & 都構想賛否 \\
\hline d) & 都構想に対する期待 & $\begin{array}{l}\text { d) } \\
\text { e) }\end{array}$ & $\begin{array}{l}\text { 都構想に対する期待 } \\
\text { 都構想に関する情報の評価 }\end{array}$ \\
\hline & $\begin{array}{l}\text { 都構想の事実情報に対する認知 } \\
\text { 統一地方選の投票予定先と判断基準 }\end{array}$ & & 都構想の事実情報に対する認知 \\
\hline & 橋下徹大阪市長に対する評価 & & 橋下徹大阪市長に対する評価 \\
\hline f) & $\begin{array}{l}\text { 都構想参考情報 } \\
\text { 居住地 } \\
\text { 最終学歴 } \\
\text { 大衆性(自己閉塞性·傲慢性) } \\
\text { 地域愛着 }\end{array}$ & f) & $\begin{array}{l}\text { 都構想参考情報 } \\
\text { 国政政策に対する意識 }\end{array}$ \\
\hline
\end{tabular}



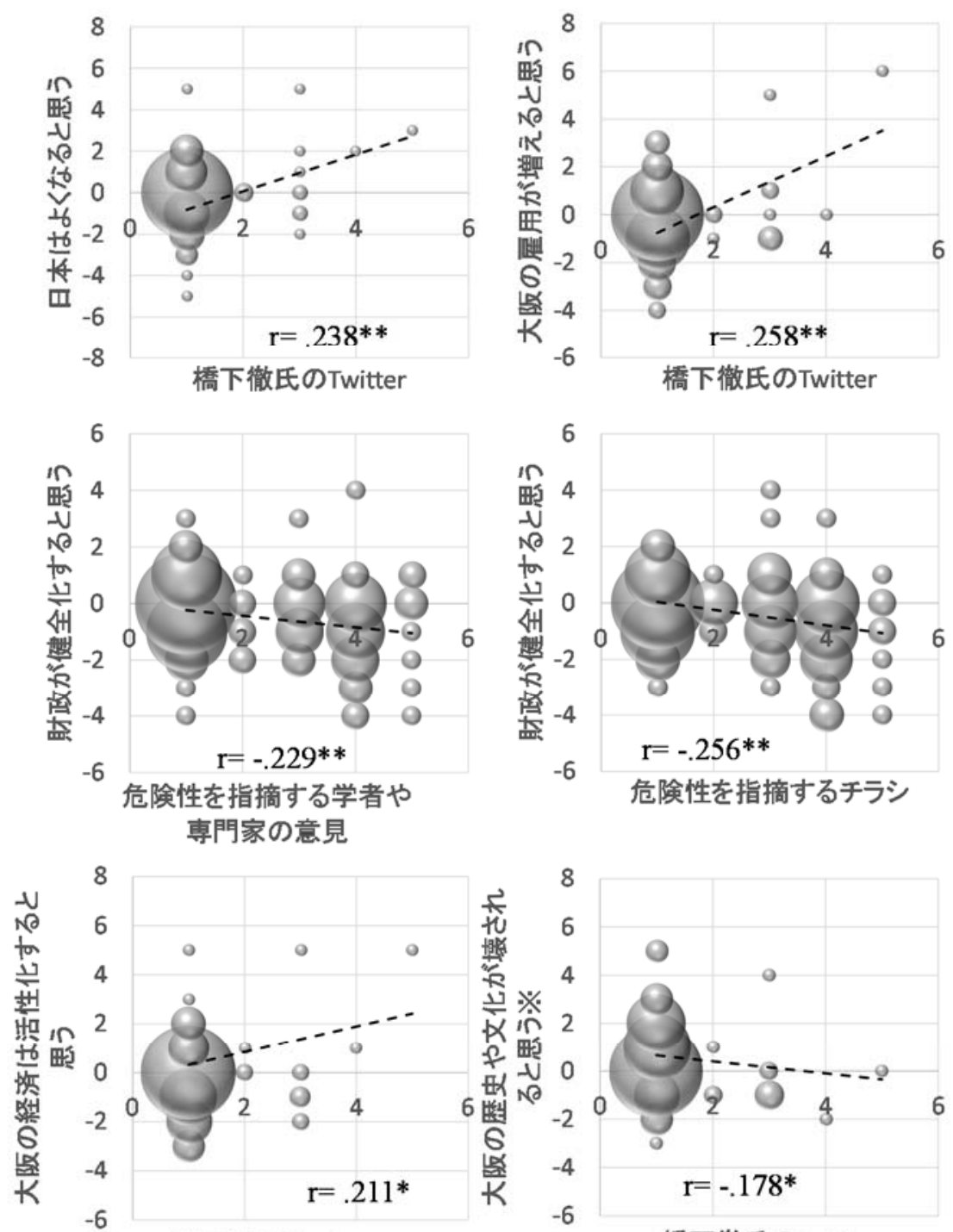

橋下徹氏のTwitter
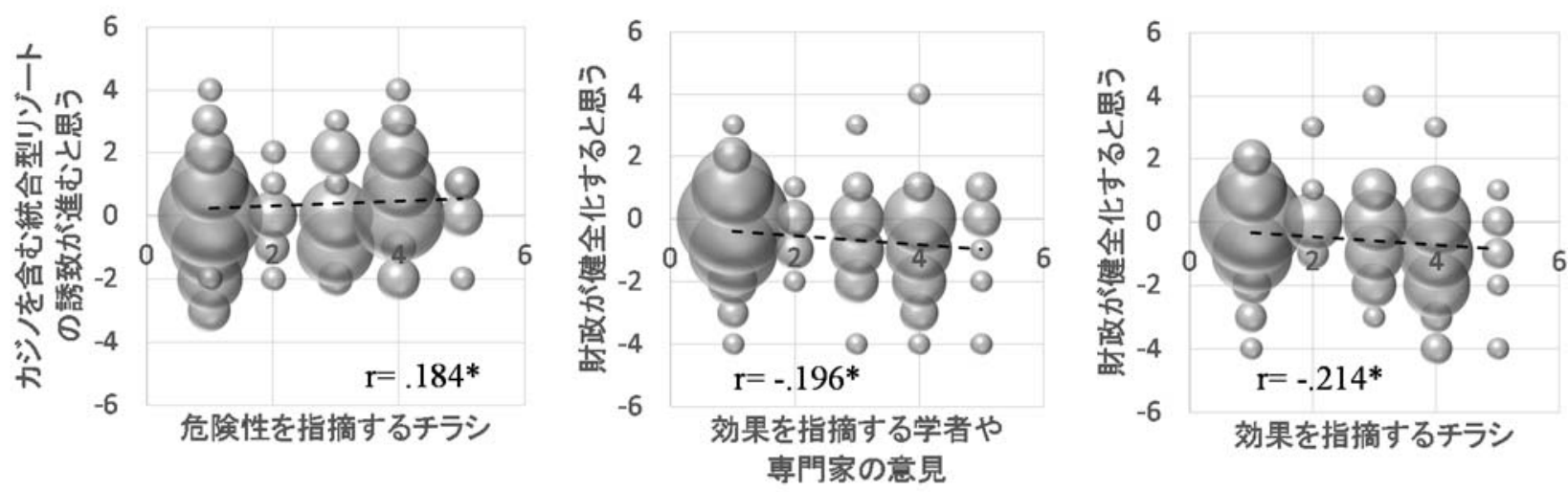

付図-1 否定的変化群における「都構想に関する各種情報媒体の参考の程度」と

${ }^{*} \mathrm{p}<.05 \quad * * \mathrm{p}<.01 \quad * * * \mathrm{p}<.001$ 「住民投票前後の都構想期待感の変化量」の散布図（バブルチャート）

\section{参考文献}

1) 藤井聡，村上弘，森裕之（編著）：大都市自治を問 う大阪・橋下市政の検証，学芸出版社，2015.

2) 松村明 : 大辞林, 三省堂, 1990 .
3) J. S. ミル：代議制統治論, 岩波文庫, 1997.

4) 岡本三彦：自治体の政策過程における住民投票, 議 員のための政策情報誌，Vol. 37,pp. 13-23, 2013.

5) 朝日新聞デジタル，http://www.asahi.com/articles/ 
ASH5K5QR5H5KPTIL02G.html，2015.5.17.21:42 配信

6) 羽鳥剛史, 小林潔司：利益集団の発言が住民投票に 及ぼす影響，土木学会論文集，No. 774/IV-66, pp. 131146, 2005.

7) 尾崎和典, 世論調査から見たメディア選挙, 選挙研 究, Vol. 22, pp. 17-24, 2007.

8）稲増一憲, 池田謙一：多様化するテレビ報道と，有 権者の選挙への関心および政治への関与との関連 : 選挙報道の内容分析と大規模社会調査の融合を通し て, 社会心理学研究, Vol. 25, No. 1, pp. 42-52, 2009.

9) 産経 WEST, http://www.sankei.com/west/news/150405/ wst1504050065-n1.html, 2015.4.5 23:30 配信

10）橋下徹, 2015.4.15.6:26:41 配信, http://twitter.com/t ishin (最終閲覧日：2015 年 12 月 22 日)

11) 金山智子：離島のコミュニティ形成とコミュニケー ションの発達〜徳之島編〜, Journal of Global Media Studies, Vol. 9, pp. 31-40, 2011.

12) 大阪維新の会ホームページ「大阪都構想について, 都構想の Q\&A（よくあるご質問）」http://oneosaka.jp /tokoso/q-and-a1.html (最終閲覧日：2015 年 12 月 22 日)

13）日本共産党大阪府委員会ホームページ「ズバリわか る大阪都」，http://www.jcp-osaka.jp/pages/hendayo- ishinnokai/osakatokousou-qa/otqa ver 20140127/ tokousou_qa_vol1_03 (最終閲覧日：2015 年 12 月 22 日)

14) 日本経済新聞, 「都構想協定書巡り対決 大阪市議会, 公明・自民と橋下市長」，2014.10.23 2:03 配信

15) Petty, R. E. and Cacioppo, J. T. : The Elaboration Likelihood Model of persuasion, New York: Academic Press, 1986.

16）尾花恭介, 広瀬幸雄, 藤井聡 : 精緻化見込みモデル から考察した NIMBY 型事業の受容に及ぼす手続き公 正さの影響, 土木学会論文集 D3 (土木計画学), Vol. 69, No. 4, pp. 267-275, 2013.

17) 森沢幸博：ソーシャルメディアによる感情共有と創 造的思考の関係, 埼玉女子短期大学研究紀要, No. 29, pp. 45-61, 2014.

18）馬場健司, 小杉素子：熟議による社会的意思決定プ

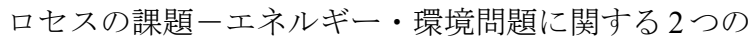
討論型世論調查からの示唆一, 電力中央研究所研究 報告書（電力中央研究所報告），2013.

19) 橋下徹, http://twitter.com/t_ishin (最終閲覧日：2016年 8 月 22 日)

(2016. 1.13 受付)

\section{ANALYSIS OF A RELATION BETWEEN POLICY DECISION AND MEDIA CONTACT - A CASE STUDY OF THE OSAKA METROPOLIS PLAN-}

\section{Ayu MIYAKAWA, Kenshiro TANAKA and Satoshi FUJII}

This study conducted questionnaire research in Osaka city in order to examine the effect of the media which serves information for people regarding the Osaka Metropolis plan. As a result, people in contact with the media, such as TV or newspaper which the pros and cons are shown, do not change their opinion because it is difficult to sift the genuine from the false.

Based on the elaboration likelihood model, when elaboration is high, the central persuasive route is more likely to occur; conversely, when the elaboration is low, the peripheral route is more likely to occur. In this case, it is suggested that people who referred to the central route changed their opinion to disapprove the Osaka Metropolis plan, and people who referred to the peripheral route changed their opinion to approve the plan. 